\title{
ILUZJA PIENIĄDZA
}

\section{- ISTOTA, KOSZTY SPOKECZNO-GOSPODARCZE I SPOSOBY ICH REDUKCJI W ŚWIETLE KONCEPCJI ZRÓWNOWAŻONEGO ROZWOJU}

Słowa kluczowe: iluzja pieniądza, zrównoważony rozwój, finanse behawioralne. Klasyfikacja JEL: E40, G02

\begin{abstract}
Abstrakt: Sugerowanie się przy podejmowaniu decyzji gospodarczych wyłącznie lub głównie nominalnymi kategoriami pieniężnymi, czyli tzw. iluzja pieniądza, może generować poważne zaburzenia gospodarcze. W świetle koncepcji zrównoważonego rozwoju jest to zjawisko negatywne, mogące destabilizować zarówno ład gospodarczy, jak i społeczny. Dzieje się to zwłaszcza poprzez zniekształcanie rozkładu dochodów w społeczeństwie oraz pogłębianie nierównowag rynków w sytuacjach kryzysowych. Dlatego pożądane są działania redukujące skalę iluzji pieniądza, a zwłaszcza polityka państwa możliwie sprzyjająca stabilności siły nabywczej pieniądza i równoległa intensyfikacja powszechnej edukacji społeczeństwa odnośnie do mechanizmów iluzji pieniądza, od poziomu szkoły średniej począwszy.
\end{abstract}

\footnotetext{
MONEY ILLUSION - THE ESSENCE, SOCIAL AND ECONOMIC COSTS AND WAYS OF THEIR REDUCTION IN THE LIGHT OF SUSTAINABLE DEVELOPMENT CONCEPT
}

Keywords: money illusion, sustainable development, behavioral finance. JEL Classification: E40, G02.

Data wpłynięcia: 23.06.2013; data zaakceptowania: 08.11.2013.

* Dane kontaktowe: robhuski@umk.pl, Katedra Zarządzania Finansami, Wydział Nauk Ekonomicznych i Zarządzania, Uniwersytet Mikołaja Kopernika, ul. Gagarina 13a, 87-100 Toruń, tel. 603663556. 


\begin{abstract}
To be deceived, only or mainly, by nominal monetary categories while undertaking economic decisions, what is called a money illusion, may generate serious economic disturbances. In the light of sustainable development concept, it is negative phenomenon that may destabilize economic and social orders. It works mainly through distortion of income distribution among society and deepening market imbalances in time of crisis. Therefore, it is desirable to undertake activities that lead to reduction of money illusion, with special regard to the policy of state that supports stability of money purchasing power together with parallel intensive education of society about mechanics of money illusion, starting from secondary school level.
\end{abstract}

Translated by Robert Huterski

\title{
WSTĘP
}

Iluzja pieniądza wskazuje na istnienie znaczących ograniczeń ludzkiej racjonalności w podejmowaniu decyzji gospodarczych, co podważa istotę teorii racjonalnych oczekiwań. W 1972 r., w okresie dominacji racjonalnych oczekiwań jako sposobu widzenia mechanizmu ludzkich decyzji, James Tobin (sam akceptujący istotność iluzji pieniądza) żartobliwie stwierdził, że: „Teoretyk ekonomii nie może oczywiście popełnić większej zbrodni niż założyć istnienie iluzji pieniądza".

Celem niniejszego artykułu jest przegląd podstawowych problemów generowanych przez iluzję pieniądza oraz ich ocena w świetle założeń koncepcji zrównoważonego rozwoju. Ze względu na założoną objętość artykułu, spośród obszernej literatury wykorzystano jedynie wybrane publikacje odnoszące się do danego aspektu iluzji pieniądza, pomijając opracowania zgodne w założeniach, a jedynie stosujące odmienne metody badawcze.

Koncepcja zrównoważonego rozwoju ze swej istoty podkreśla znaczenie relacji między ładem środowiskowym, gospodarczym i społecznym. Kryzys gospodarczy ostatnich lat, którego korzeniem jest kryzys finansowy, zwrócił uwagę badaczy zrównoważonego rozwoju na rosnące problemy z uporządkowaniem i ustabilizowaniem relacji w ramach ładów społecznego i gospodarczego, a także między nimi. Postęp w uporządkowaniu i stabilizacji tych relacji umożliwi większą skalę coraz pilniejszej redukcji zagrożeń dla ładu środowiskowego, wygenerowanych przez interakcje gospodarcze i społeczne (Hull 2011, 38). W tym kontekście, dotychczas przeważnie pomijanym zagadnieniem w ramach koncepcji zrównoważonego rozwoju, wymagającym jednak szczegółowej i wszechstronnej analizy, są implikacje zarówno funkcjonowania współczesnego pieniądza, jak i ukształtowanego przez jego cechy systemu fi- 
nansowego, istotnie wpływające na możliwości realizowania zrównoważonego rozwoju.

W odróżnieniu od pieniądza kruszcowego, panujący dziś w światowej gospodarce pieniądz fiducjarny funkcjonuje tylko dzięki zaufaniu użytkowników, gdyż jego emitent nie podejmuje się wymiany tego pieniądza na jakiekolwiek inne dobro, a sam materiał, z którego powstaje fiducjarny pieniądz papierowy (tym bardziej elektroniczny), nie ma samoistnej wartości użytkowej, jaką posiadał pieniądz towarowy. Oznacza to brak zewnętrznej kotwicy rozmiarów jego emisji, a w konsekwencji także brak kotwicy siły nabywczej, która staje się przez to znacznie bardziej podatna na zaburzenia (z bardziej aktualnych i spektakularnych przykładów, np. hiperinflacja w Zimbabwe w czerwcu 2008 r., rzędu $11 \mathrm{mln}$ procent w skali roku). Przejawem tego jest intensyfikacja zmienności relacji między nominalną i realną wartością pieniądza, co zwiększa prawdopodobieństwo błędnej oceny tych relacji przez uczestników rynku, czyli wystąpienia zjawiska iluzji pieniądza (Eber 2010, 25).

Ludzie koncentrują się na wartości nominalnej, ponieważ jest istotna, łatwa do ustalenia i w wielu przypadkach dostarcza rozsądnego przybliżenia oszacowania realnej wartości. Co więcej, koresponduje to z powszechnym przeświadczeniem, że większość obiektów wokół nas, a zwłaszcza jednostek miary, nie podlega częstym zmianom (Shafir i in. 1997, 366). Zjawisko to ma charakter uniwersalny, ale ze swej natury zasługuje na szczególną uwagę w kraju takim jak Polska, ze względu na jego wciąż znaczny potencjał niestabilności gospodarczej oraz relatywnie niski poziom wiedzy postsocjalistycznego społeczeństwa o mechanizmach pieniężnych.

Znaczenie problemu iluzji pieniądza z punktu widzenia zrównoważonego rozwoju wiąże się z generowaniem przez to zjawisko efektów redystrybucyjnych w rozkładzie dochodu w społeczeństwie oraz wzmaganiem nierównowag w przebiegu procesów gospodarczych, prowadzących do sytuacji kryzysowych. Wywołują one dysharmonię między ładem gospodarczym i społecznym, co wzmaga negatywne skutki zaburzeń w ramach tych ładów dla ładu środowiskowego. Przykładem może być hiszpański boom budowlany do 2009 r., napędzony w dużej mierze przejściowo sztucznie tanimi i dostępnymi kredytami oraz regulacjami promującymi zmianę kwalifikacji gruntów na budowlane (Etxezarreta i in. 2011, 12). Pozostały po nim znaczne zmiany środowiskowe spowodowane żywiołową zabudową, której znaczna część obecnie niszczeje niewykorzystana. 


\section{METODYKA BADAŃ I PRZEBIEG PROCESU BADAWCZEGO}

Badania przeprowadzono na podstawie analizy literatury dotyczącej iluzji pieniądza. Dominacja źródeł angielskojęzycznych wynika z ograniczonego zakresu empirycznych i modelowych badań tego problemu w literaturze polskiej. Po sformułowaniu istoty iluzji pieniądza przystąpiono do przeglądu obszarów diagnozowania jego występowania, a następnie sformułowano propozycje działań ograniczających negatywne skutki społeczno-gospodarcze tego zjawiska z punktu widzenia koncepcji zrównoważonego rozwoju.

\section{ISTOTA ILUZJI PIENIĄDZA}

Istotą iluzji pieniądza jest przewaga myślenia w nominalnych kategoriach pieniężnych nad myśleniem w realnych kategoriach pieniężnych (Shafir i in. 1997, 341). Zjawisko to może zatem wystąpić nawet przy dysponowaniu informacjami zarówno w ujęciu nominalnym, jak i realnym. Wystarczy, że pojawi się sytuacja zaburzająca właściwy odczyt tych informacji. Najczęściej wiąże się to ze zjawiskami inflacyjnymi lub deflacyjnymi, które głównie poprzez zmiany cen i płac zmieniają realną siłę nabywczą jednostki pieniężnej, co nie jest właściwie odczytywane przez podmioty rynkowe. Przykładowo: podwyżka płacy nominalnej o $2 \% \mathrm{w}$ okresie inflacji na poziomie $4 \%$ jest przez pracowników inaczej (lepiej) odbierana niż obniżka płacy nominalnej o $2 \%$ w okresie $2 \%$ deflacji (gorzej), chociaż ekonomicznie korzystniejsze jest to drugie (podobnie, Raghubir, Srivastava 2002, 335).

Należy także uwzględnić skutki doświadczeń czy wzorców zachowań zakorzenionych w ludzkich umysłach w okresach inflacji czy deflacji, które mogą wpływać na odtwarzanie schematów ocen relacji między nominalnymi i realnymi kategoriami pieniężnymi nawet w okresach stabilności cen i płac (Raghubir, Srivastava 2002, 335). Szczególnym wariantem tego problemu jest zniekształcenie odczytu wspomnianych relacji przy posługiwaniu się walutą krajową i walutami obcymi (Fisher 1928, 4). Zmiany kursu walutowego mogą być wywołane zjawiskami inflacyjnymi lub deflacyjnymi zachodzącymi tylko w kraju waluty obcej. Mogą one wynikać również z czynników politycznych albo przepływów kapitałowych w kraju waluty obcej, które dopiero z czasem mogą skutkować inflacją lub deflacją, ale nie muszą. Nie należy więc sprowadzać iluzji pieniądza tylko do adaptacyjnych oczekiwań podmiotów rynkowych, bazujących na przeszłych poziomach zmiennych monetarnych (Shafir 
i in. 1997, 367). Może też oddziaływać sam efekt większego nominału (face value effect) albo różnica w łatwości podzielenia względem pomnożenia przy danych układach kursowych, rzutująca na prawidłowość przeliczania relacji jednostek waluty krajowej względem jednostek waluty obcej i w rezultacie na ostateczną decyzję o transakcji.

Skutki iluzji pieniądza objawiają się w podejmowaniu przez osoby, przedsiębiorstwa, a nawet (według niektórych ekonomistów - zwłaszcza) przez władze publiczne (Howitt, 1987), innych decyzji niż te, które zostałyby podjęte bez sugerowania się nominalnymi kategoriami pieniężnymi. Występowanie iluzji pieniądza wiąże się z systematycznym, grupowym popełnianiem błędów przez uczestników rynku. To zaś oznacza nieistnienie w pełni racjonalnie działającego homo oeconomicus i podważa mechaniczną czy wręcz astrofizykalną wizję funkcjonowania gospodarki, wyłaniającą się z pierwotnej wersji teorii racjonalnych oczekiwań (Thaler 1992), stanowiącej istotny filar wielu szkół ekonomii neoklasycznej.

Negujący występowanie i ekonomiczną istotność tego zjawiska często pomijają cechę zmienności zakresu iluzji pieniądza, a przez to i skutków przez nią wywoływanych (Noussair, Richter, Tyran 2008,1). Generalnie, od strony istotności potencjalnych skutków gospodarczych, iluzja pieniądza jest zjawiskiem stopniowalnym i usuwalnym, o ile w danej sytuacji możliwe jest ograniczenie zakresu lub zlikwidowanie przyczyny popełniania przez uczestników rynku błędów w ocenie relacji między nominalnymi i realnymi kategoriami pieniężnymi. W dalszej części artykułu będzie zasygnalizowane powiązanie między zmiennością gospodarki a osłabieniem lub nasileniem występowania iluzji pieniądza.

Iluzja pieniądza bywa sprowadzana do prostego efektu asymetrii informacji jako źródła błędnych decyzji, co mogłoby sugerować, że bez asymetrii informacji wystąpienie iluzji pieniądza jest niemożliwe. Zdaniem autora jest to tylko jeden z kilku czynników sprzyjających powstawaniu iluzji pieniądza, który nie wyjaśnia w pełni okresów powszechności i długotrwałości utrzymywania się tego zjawiska. Sednem iluzji pieniądza jest wnioskowanie zdominowane przez nominalne ujęcie kategorii pieniężnej, prowadzące do podjęcia błędnej decyzji. Podstawowe przyczyny oparcia decyzji wyłącznie na ujęciu nominalnym, a także niedoszacowania znaczenia ujęcia realnego mimo świadomości jego istnienia, które mieszczą się w procesie decyzyjnym, można uporządkować następująco:

- nierówny dostęp do informacji jako danych nieprzetworzonych (wyżej wspomniana asymetria informacji); 
- równy dostęp do informacji przy niejednakowej wiedzy o instrumentarium potrzebnym do ich prawidłowego wykorzystania lub przy niejednakowym dostępie do takiego instrumentarium (zróżnicowane możliwości postawienia trafnej diagnozy problemu na podstawie takich samych danych);

- równy dostęp do informacji i do instrumentarium potrzebnego do ich prawidłowego wykorzystania oraz równa wiedza o posługiwaniu się nim przy zróżnicowanym tempie podejmowania decyzji na podstawie posiadanych i przetworzonych informacji, zależnym choćby od uwarunkowań osobniczych i środowiskowych (luka czasowa między diagnozą problemu a ustaleniem metody jego rozwiązania);

- równy dostęp do informacji, równa wiedza o instrumentarium potrzebnym do ich prawidłowego wykorzystania i równy dostęp do niego oraz równe tempo podejmowania decyzji przy zróżnicowaniu stopnia konsekwencji we wdrażaniu tych decyzji, szczególnie ważne w bardziej złożonych sytuacjach (luka czasowa między diagnozą problemu łącznie z ustaleniem metody jego rozwiązania a pełnym zastosowaniem przyjętego rozwiązania i/lub pojawieniem się jego efektów).

Oczywiście możliwe są inne kombinacje powyższych elementów, jak choćby różna wiedza poszczególnych uczestników rynku o instrumentarium przetwarzania posiadanych identycznych informacji w połączeniu z luką czasową poprzedzającą wdrożenie decyzji. Powyżej ograniczono się do przeglądu kluczowych faz procesu podejmowania decyzji, a zagadnienie jest oczywiście znacznie bardziej złożone.

Iluzja pieniądza wymaga też uwzględnienia przy analizie wielu zjawisk decyzyjnych, takich jak: kadrowanie (framing), zakotwiczenie i dostosowanie (anchoring and adjustment), rachunkowość mentalna (mental accounting) czy niechęć do strat (loss-aversion) (Shafir i in. 1997, 366). Należy także pamiętać o istotnych powiązaniach między problemem nie-neurtalności pieniądza, zwłaszcza w krótkim okresie, a iluzją pieniądza (Harkness 1978, 711). Silna swego czasu pozycja teorii racjonalnych oczekiwań (zwłaszcza w latach 70. i 80. XX w.) spowodowała unikanie przez badaczy wyjaśniania mechanizmami iluzji pieniądza ewidentnego krótkookresowego wpływu nominalnych szoków pieniężnych na wzrost gospodarczy (Fehr, Tyran 2001, 1241). Współcześnie jednak to podejście wraca, wraz z przechodzeniem racjonalnych oczekiwań z pozycji szkoły myśli ekonomicznej na pozycję popularnej wśród ekonomistów techniki modelowania (Sargent 2007). 


\section{OBSZARY DIAGNOZOWANIA WYSTĘPOWANIA ILUZJI PIENIĄDZA}

Chociaż iluzja pieniądza ma uniwersalną istotę dominacji nominalnych kategorii pieniężnych nad realnymi prowadzącej do podejmowania błędnych decyzji, to głębsza analiza tego zjawiska odsłania wiele specyficznych uwarunkowań jego występowania.

\subsection{Inflacja i deflacja}

Najwięcej uwagi poświęca się w literaturze przedmiotu mechanizmom reakcji na inflacyjne i deflacyjne szoki nominalne na poziomie zagregowanym (w odniesieniu do ogółu cen i płac w gospodarce) (Noussair i in. 2008, 18; Shafir i in. 1997, 368).

Według Shafira i in. (1997, 367), zaakceptowanie poglądu, że ludzkie decyzje nie zawsze odpowiadają klasycznym kalkulacjom, a w konsekwencji, że ludzie mogą być podatni na iluzję pieniądza, rodzi pogląd, że różne tempa/stopy inflacji mają normatywne implikacje (w sensie wnioskowania o właściwej reakcji, np. o pożądanym charakterze polityki pieniężnej) odmienne od zakładanych przez standardowe modele racjonalne. Łagodna inflacja będzie zatem wpływała na alokację na przykład siły roboczej i nieruchomości tym bardziej, im bardziej ludzie są niechętni np. obniżkom płac nominalnych czy stratom w nominalnej wartości posiadanego domu, gdyż idzie to w parze z osłabieniem lub brakiem ich reakcji na straty realne, gdy nominalne wartości są stałe lub rosną. Opierając swoje wnioski na charakterystyce systemu emerytalnego w USA Shafir i in. $(1997,367)$ wskazują, że iluzja pieniądza w efekcie inflacji może skutkować pogłębianiem się ubóstwa wśród starszych osób, jako rezultat wybierania przez nich nominalnych świadczeń z funduszy emerytalnych w połączeniu z niewłaściwym rozpoznawaniem przez nich różnicy między realnymi i nominalnymi stopami procentowymi. Należy dodać, że według podobnego mechanizmu iluzja pieniądza może przyczyniać się do większych strat w majątkach starszych osób w związku z obciążaniem przez nie nieruchomości w ramach odwróconego kredytu hipotecznego.

Shafir i in. $(1997,368)$ zakładają również, że poprzez podobne mechanizmy iluzja pieniądza może wpływać na międzynarodowy handel i turystykę. Z tych powodów podkreślają oni, że przy wyborze optymalnego celu inflacyjnego nie wolno przeoczyć efektów iluzji pieniądza i to zwłaszcza tych, które występują, gdy zestawia się zerową inflację z jej innymi niskimi poziomami. Warto zauwa- 
żyć, że skutki iluzji pieniądza w efekcie utożsamiania niskiej inflacji z zerową (niekorzystne dla jednej strony transakcji, korzystne dla drugiej) będą znacząco narastały przy decyzjach finansowych długookresowych, takich właśnie jak ocena atrakcyjności zaciągnięcia kredytu hipotecznego względem płatności rat czynszu za najem czy wybór schematu wypłat świadczeń o charakterze emerytalnym (w tym z odwróconego kredytu hipotecznego).

Według badań Noussairego i in. $(2008,18)$, ceny bardzo szybko wracają do poziomu realnego, gdy szok ma charakter inflacyjny, ale dostosowują się powoli po szoku deflacyjnym i tego rodzaju zakłócenia w kształtowaniu się cen realnych należy przypisać iluzji pieniądza. Wzmacnianie przez deflację inercji cen nominalnych wiążą oni z różnym tempem podejmowania decyzji przez uczestników transakcji rynkowych. Wśród owych uczestników Noussair i in. (2008, 18) wyróżniają Racjonalnych Kontrahentów (Rational Traders), zdolnych do szybkiego i prawidłowego odczytywania relacji między nominalnymi i realnymi kategoriami pieniężnymi oraz Tendencyjnych Kontrahentów (Biased Traders), podejmujących opóźnione i zniekształcone decyzje. Tendencyjni Kontrahenci podlegają zakłóceniom odczytu powyższych relacji ze względu na awersję do strat nominalnych (wszelkich, gdyż nie uświadamiają sobie możliwości realnych zysków przy nominalnych stratach) oraz specyficzny sposób klasyfikowania transakcji. Specyficzne klasyfikowanie oznacza traktowanie zakupu dobra oraz następującej po nim odsprzedaży tego dobra po wyższej cenie nominalnej jako dwóch powiązanych transakcji, ale błędne postrzeganie odwrotnej kolejności, czyli sprzedaży danego dobra, po której następuje zakup takiego dobra po niższej cenie nominalnej, jako dwóch niezależnych transakcji.

Racjonalni Kontrahenci kupują, gdy cena rynkowa jest niska, a sprzedają, gdy cena rynkowa jest wysoka w relacji do wartości fundamentalnej. Noussair i in. $(2008,19)$ wskazują, że w czasie szoku deflacyjnego Tendencyjni Kontrahenci, kierując się wartościami nominalnymi, stają się niechętni do sprzedaży swoich składników majątku po cenach nominalnych niższych niż sami zapłacili, nabywając je, i w rezultacie ograniczają podaż. Powoduje to presję wzrostową na ceny realne, której objawem na rynku jest nominalna inercja cen, gdyż ceny nominalne obniżą się wolniej i ostatecznie w mniejszym stopniu niż gdyby w transakcjach brali udział wyłącznie uczestnicy rynku niepodlegający iluzji pieniądza.

Fehr i Tyran $(2004,3)$ zwracają uwagę, że istotnym czynnikiem wzmacniającym występowanie iluzji pieniądza w sytuacji, gdy istnieje wiele potencjalnych punktów równowagi, jest strategiczna niepewność co do zachowań innych 
uczestników rynku (graczy), specyficznie kształtująca wybór nowych punktów równowagi. Silna strategiczna niepewność utrudnia indywidualną optymalizację decyzji, dalece redukując możliwości uczenia się, którego efekty z biegiem czasu mogłyby zredukować iluzję pieniądza. Prowadzi to do długotrwałego blokowania się uczestników rynku w nieefektywnych (w sensie Pareto) punktach równowagi, co powoduje trwałe negatywne skutki dla gospodarki.

Według badań Fehra i Tyrana $(2004,16)$ pozornie nieistotne różnice w przedstawianiu rezultatów (potencjalnych wygranych) mają znaczące skutki dla wyboru punktów równowagi przez uczestników gry rynkowej o wielu potencjalnych równowagach. Gdy rezultaty zostały przedstawione w ujęciu nominalnym, 84\% uczestników ostatecznie skłoniło się do Pareto-nieefektywnego punktu równowagi, za to przedstawienie rezultatów w ujęciu realnym spowodowało, że 98\% uczestników ostatecznie przyjęło Pareto-efektywny punkt równowagi. Na tej podstawie Fehr i Tyran $(2004,16)$ wnioskują, że uczenie się w środowiskach strategicznych z wieloma równowagami może być trudne lub niemożliwe albo, jeśli wystąpi, może być zbyt spóźnione, by znacząco wpłynąć na zagregowane rezultaty wyborów, przez co wpływ iluzji pieniądza na te rezultaty będzie silniejszy i trwalszy niż w innych uwarunkowaniach.

\subsection{Szoki nominalne}

Badane są również decyzje w reakcji na pozytywne i negatywne szoki nominalne, co jest w swej istocie zawężeniem problematyki inflacyjnej i deflacyjnej przez położenie nacisku na zmiany podaży pieniądza jako źródła niestabilności siły nabywczej pieniądza, prowadzącej do ujawniania się iluzji pieniądza. Według Fehra i Tyrana $(2001,1239)$ wyniki badań wskazują, że negatywne i pozytywne szoki nominalne mają asymetryczne efekty z powodu iluzji pieniądza. Gdy po szoku negatywnym inercja nominalna jest znacząca i długotrwała, jest ona raczej niewielka po szoku pozytywnym. Zjawisko, że negatywne szoki nominalne mają efekt redukujący produkcję, a szoki pozytywne zdają się nie wpływać na produkcję, potwierdzają również inne badania, jak na przykład Covera (1992) oraz DeLonga, Summersa (1988).

Fehr i Tyran $(2001,1239)$ stwierdzają również, że nawet niewielki zakres iluzji pieniądza na poziomie indywidualnym może spowodować poważną inercję nominalną po negatywnym szoku nominalnym. Inaczej ujmując, dla wystąpienia silnego spowolnienia dostosowań cen i płac nominalnych w efekcie ograniczenia podaży pieniądza nie jest konieczne, by pod wpływem iluzji 
pieniądza znalazła się większość uczestników rynku, gdyż reakcje tej części z nich, która iluzji pieniądza podlega, mogą generować swoisty efekt domina.

W uzasadnieniu tego stwierdzenia Fehr i Tyran $(2001,1259)$ wskazują, że specyficzne powiązania między płacowymi zachowaniami pracodawców i pracobiorców mogą wzmagać przekładanie się iluzji pieniądza i wywoływanej przez nią inercji po stronie płac na inercję cen. Na przykład, jeśli firmy przewidują, że pracownicy będą się bronili przed obniżką płac po negatywnym szoku pieniężnym, to te firmy będą prawdopodobnie niechętne obniżaniu cen, ponieważ to zmniejszyłoby ich zyski. W konsekwencji, jeśli ceny pozostaną wysokie, to pracownicy mogą czuć się usprawiedliwieni w swoim oporze przed redukcją płac. Zatem niechęć do obniżenia płac i cen może się wzajemnie napędzać przez dłuższy czas.

Jest to zgodne z poglądem wyrażonym przez Shafira i in. (1997, 368), że ujmując bardziej ogólnie, poznawcze (kognitywne) iluzje części jednostek mogą mieć istotne skutki ekonomiczne. Koresponduje to z wynikami innych wcześniejszych badań nad zachowaniami uczestników rynku stwierdzającymi, że niewielkie odchylenie od optymalności części jednostek może mieć istotny wpływ na charakterystykę gospodarczych równowag (np. Akerlof, Yellen 1985, Haltiwanger, Waldman 1985 oraz Russel, Thaler 1985).

\subsection{Nieruchomości}

Wpływ iluzji pieniądza na decyzje uczestników rynku nieruchomości został już wyżej zasygnalizowany i jest on uznawany za na tyle ważny, że zagadnieniu temu są poświęcone odrębne opracowania. Przykładowo Brunnermeie i Julliard (2008, 2-3) stwierdzają, że osoby opierające swoje decyzje - czy wynająć, czy kupić mieszkanie - na nominalnym porównaniu miesięcznego czynszu za najem z miesięczną ratą kredytu hipotecznego o stałym oprocentowaniu, są poddane wpływowi iluzji pieniądza. Zakładają one błędnie, że realne i nominalne stopy procentowe zawsze podlegają silnie, jeśli nie w pełni, skorelowanym zmianom. Z tego powodu błędnie łączą spadek inflacji ze spadkiem realnych stóp procentowych i w konsekwencji nie potrafią właściwie oszacować realnego kosztu przyszłych płatności kredytu hipotecznego. W ten sposób tworzą oni presję na wzrost realnych cen mieszkań w okresie spadku inflacji, gdyż wtedy, patrząc z perspektywy nominalnej, uznają nabycie mieszkania za bardziej atrakcyjne niż dotychczas i zgłaszają dodatkowy popyt. 
Warto zauważyć, że w innych opracowaniach (np. Shafir i in. 1997, 367, Noussair, i in. 2008, 19) wskazuje się na wpływ iluzji pieniądza w okresach deflacji na ograniczenie podaży mieszkań przez ich właścicieli, ze względu na ich awersję do strat nominalnych. Można to również przełożyć na okresy wyraźnego wyhamowania tempa inflacji, biorąc pod uwagę zakotwiczone jeszcze w czasie intensywnej inflacji wyobrażenia właścicieli o godziwym wzroście nominalnej ceny ich nieruchomości. Jest to dynamiczna wersja klasycznego problemu iluzji pieniądza, dotycząca błędów w odczy tywaniu zmieniających się relacji między nominalnymi i realnymi kategoriami pieniężnymi, powodowanych preferowaniem ujęcia nominalnego jako wygodniejszego.

Na przykładzie rynku mieszkaniowego USA Brunnermeier i Julliard (2008, 37) wskazują również, że dowody zjawiska zagregowanej iluzji pieniądza na rynku mieszkaniowym można pogodzić z obserwowaną heterogenicznością w regionalnych (stanowych) zachowaniach cen, jeśli właściwie uwzględni się międzystanowe różnice w relatywnej rzadkości gruntów pod zabudowę. Jest to zarazem wskazówka, jak łatwo iluzja pieniądza może się ukryć za innymi zjawiskami.

\subsection{Papiery wartościowe}

Badania nad iluzją pieniądza na rynku papierów wartościowych dotyczą instrumentów o stałym nominalnym dochodzie, jak klasyczne obligacje i bony (zwłaszcza skarbowe) oraz tych o zmiennym dochodzie, jak akcje i indeksowane obligacje i bony (Garcia, van Rixtel 2007, 16). Iluzją pieniądza próbuje się wyjaśnić znaczną przewagę dochodowości akcji nad nominalnymi obligacjami i bonami. Ta przewaga jest pochodną zjawiska, że to inwestorzy na rynku akcji, ale nie na rynku obligacji, podlegają iluzji pieniądza, w rzeczywistości dyskontując realne przepływy pieniężne według nominalnych stóp (Cohen i in. 2005, 4-5). Obligacje generują przepływy pieniężne, które są nominalnie stałe, i dlatego oszacowanie stopy wzrostu tych przepływów dla obligacji jest znacznie łatwiejsze niż oszacowanie długookresowego oczekiwanego wzrostu przepływów pieniężnych dla akcji. W rezultacie często wysoka inflacja współistnieje z niskimi cenami akcji w stosunku do obligacji i akcje dają wyższe niż uzasadnione przyszłe zwroty w stosunku do krótkoterminowych obligacji lub bonów, co wraz z innymi wcześniejszymi badaniami szeregów czasowych wspiera hipotezę iluzji pieniądza Modiglianiego-Cohna (Modigliani, Cohn 1979). Cohen i in. $(2005,22)$ dowodzą, że jest to zjawisko niezależne od ryzykowności dane- 
go rodzaju akcji i ten stały efekt zmienia się w przybliżeniu jak jeden do jednego wraz ze zmianą stopy inflacji. Równoczesne badanie wyceny bonów skarbowych, ryzykownych akcji i bezpiecznych akcji pozwala trafnie odróżnić iluzję pieniądza od innych zmian w stosunku inwestorów do ryzyka.

Zarazem Cohen i in. $(2005,1)$ obserwacjami z rynku papierów wartościowych wspierają tezę o potencjalnym nasilaniu się skłonności do iluzji pieniądza w okresach niskiej inflacji. Ich zdaniem, gdy różnica między realnymi i nominalnymi wielkościami jest mała i angażowane bieżąco stawki są relatywnie niskie, zrównanie nominalnych kwot z realnymi wartościami dostarcza wygodną i efektywną zasadę kalkulacji. Wydaje się zatem naturalne, że ludzie często ignorują stopę inflacji przy przetwarzaniu informacji na potrzeby relatywnie drobnych decyzji. Należy jednak pamiętać o powyższych rozważaniach w tym artykule, które wskazują, że potencjalne skutki takiej ignorancji są może nieistotne przy sporadycznych i krótkoterminowych transakcjach, jednak stają się poważne, gdy zaangażowanie ma charakter powtarzalny i długoterminowy, jak choćby przy rozliczeniach płatności hipotecznych czy oszczędności emerytalnych.

\subsection{Emerytury}

Ze względu na wyżej wspomniany problem emerytur, prowadzone są badania nad korzyściami z rozpowszechnienia obligacji skarbowych indeksowanych względem inflacji, w które powszechnie miałyby inwestować fundusze emerytalne. Miałoby to zbliżyć stabilność realnej wartości świadczeń otrzymywanych z funduszy emerytalnych do emerytur w publicznym systemie repartycyjnym, okresowo indeksowanych względem inflacji przez władze (Garcia, van Rixtel 2007, 16). Jednak wyjaśnienie, dlaczego obligacje indeksowane inflacyjnie są tak mało popularne, odnosi się nie tylko do braku motywacji dla emitenta (władz publicznych) po stronie podażowej, ale także do iluzji pieniądza po stronie popytowej. Pojawia się paradoks, że instrument finansowy, uważany przez wielu ekonomistów za narzędzie redukowania iluzji pieniądza w kapitałowym systemie emerytalnym, nie jest pożądany przez potencjalnych beneficjentów tego rozwiązania właśnie z powodu iluzji pieniądza, której podlegają (Garcia, van Rixtel 2007, 17). Należy dodać, że fundusze emerytalne również nie wykazują szczególnego zainteresowania upowszechnieniem obligacji indeksowanych inflacyjnie jako podstawowej kategorii posiadanych przez nie aktywów. Na marginesie, argumentem łączącym fundusze i ich klientów w tej 
pasywności jest obawa, że władze publiczne jako emitent mogą manipulować wskaźnikiem cen konsumpcyjnych lub innym, na którym indeksacja byłaby oparta, a nawet, że władze nie umiałyby prawidłowo zinterpretować powiązań między referencyjnym wskaźnikiem a właściwym poziomem indeksacji inflacyjnej swoich obligacji (Garcia, van Rixtel 2007, 17).

\section{SPOSOBY REDUKCJI SPOEECZNYCH I GOSPODARCZYCH KOSZTÓW ILUZJI PIENIĄDZA}

Zdaniem autora, z punktu widzenia koncepcji zrównoważonego rozwoju, dwie podstawowe drogi do ograniczenia negatywnych społeczno-gospodarczych skutków występowania iluzji pieniądza to, po pierwsze, utrzymywanie wewnętrznej i zewnętrznej stabilności siły nabywczej jednostki pieniądza krajowego, a po drugie, powszechne edukowanie społeczeństwa w zakresie podstawowych mechanizmów ekonomiczno-finansowych.

Pierwszy postulat oznacza, że działania władz publicznych powinny redukować zakres inflacyjnych bądź deflacyjnych odchyleń siły nabywczej pieniądza, a w każdym razie powinny unikać generowania tych odchyleń swoją aktywnością. Wymaga to właściwej i skutecznej polityki zapobiegania kryzysom gospodarczym, a zwłaszcza przeciwdziałania rozwojowi baniek spekulacyjnych, ze szczególnym uwzględnieniem stabilności rynków aktywów finansowych oraz rynku nieruchomości, gdyż to przede wszystkim te obszary generują uwarunkowania potęgujące negatywne skutki iluzji pieniądza. Oczywistym problemem $\mathrm{w}$ implementacji powyższych zaleceń jest naturalna zmienność gospodarki, a więc i naturalny dynamizm jej ram finansowych, a nadmierna ingerencja władz publicznych zniekształca procesy gospodarcze, tworząc potencjalne źródła ogólnogospodarczej niestabilności. Wnioski wyniesione z obserwacji bieżącego kryzysu gospodarczego w USA i Europie powinny jednak ułatwić odróżnianie zalążków baniek spekulacyjnych i kryzysów gospodarczych od zmian niezagrażających stabilności gospodarki jako całości. W tym świetle jednym z pierwszych działań powinno być krytyczne przyjrzenie się roli samych władz publicznych w generowaniu baniek spekulacyjnych i zagrożeń kryzysowych w rezultacie ich niewłaściwych działań mających stymulować gospodarkę jako całość, poprzez nadmierne publiczne wsparcie wybranej dziedziny lub dziedzin gospodarki względem pozostałych.

Wnioski z obserwacji uwarunkowań, przebiegu i skutków współczesnych kryzysów gospodarczych sugerują raczej, że stopień racjonalności czy niera- 
cjonalności zachowań uczestników procesów gospodarczych podlega zmianom zależnie od tego, kto i w jakich okolicznościach podejmuje decyzje. Sytuacje kryzysowe zdają się wzmagać bariery racjonalności, z iluzją pieniądza włącznie, a w okresach stabilności gospodarczej bariery te słabną, usprawiedliwiając w pewnych uwarunkowaniach założenie o racjonalności ludzi podejmujących decyzje gospodarcze.

Drugi postulat, dotyczący edukacji ekonomiczno-finansowej, tylko pozornie wydaje się dyskusyjny. Rzeczywiście Shafir i in. $(1997,367)$ stwierdzają, że ludzka tendencja do myślenia w pieniężnych kategoriach nominalnych, a nie realnych, będzie się prawdopodobnie utrzymywała niezależnie od wysiłków ekonomistów, by edukować społeczeństwo (podobnie Fehr, Tyran 2004, 16). Warto jednak zwrócić uwagę, że wątpliwości dotyczą zdolności ekonomistów do pełnego wykorzenienia iluzji pieniądza, co wcale nie przesądza o niemożności ograniczenia tego zjawiska za pomocą edukacji (Campbell, Schiller 1996, 43). Skoro za główną przyczynę uporczywości iluzji pieniądza powszechnie uznaje się to, że ludziom jest o wiele łatwiej i naturalniej myśleć w kategoriach nominalnych niż realnych, to znaczy, że edukacja może ograniczyć dysproporcje w stopniu trudności posługiwania się tymi kategoriami. Pozostaje pytanie, czy rzeczywiście leży to w interesie władz oraz części podmiotów sektora prywatnego, które mogą wykorzystywać iluzję pieniądza dla własnych korzyści, ignorując straty ponoszone przez podlegających temu zjawisku.

W ramach obowiązkowych treści nauczania przedmiotu „Podstawy przedsiębiorczości”, realizowanego obecnie w polskich szkołach średnich, Ministerstwo Edukacji Narodowej nie przewiduje wprost zagadnień dotyczących nominalnych i realnych kategorii pieniężnych (Podstawa 2011, 128-131). Pośrednio jest na to miejsce $w$ ramach treści przewidujących, że uczeń „rozróżnia formy inwestowania kapitału i dostrzega zróżnicowanie stopnia ryzyka, w zależności od rodzaju inwestycji oraz okresu inwestowania” oraz „oblicza przewidywany zysk z przykładowej inwestycji kapitałowej w krótkim i długim okresie”. Brak również takich zagadnień w ramach przedmiotu uzupełniającego „Ekonomia w praktyce" (Podstawa 2011, 132). Zdaniem autora, z myślą o zredukowaniu występowania iluzji pieniądza, już na poziomie szkół średnich należałoby przynajmniej wprowadzić podstawowe zagadnienia dotyczące skutków inflacji i deflacji, gdyż te pojęcia są obecnie pominięte. Nie wydają się one przekraczać możliwości percepcyjnych przeciętnego ucznia, skoro w ramach tego przedmiotu oczekuje się od niego wyżej przytoczonych umiejętności, czy choć- 
by, że uczeń „wymienia podstawowe wskaźniki giełdowe i wyjaśnia ich wage w podejmowaniu decyzji dotyczących inwestowania na giełdzie".

\section{I Podsumowanie}

Jak wykazano, omawiając istotę iluzji pieniądza, jest to zjawisko w pewnym zakresie stopniowalne i usuwalne. Chociaż wyżej powołane badania wskazują, że iluzji pieniądza nie da się wykorzenić całkowicie, to potencjalne korzyści społeczno-gospodarcze z ograniczenia skali tego zjawiska przemawiają za podjęciem odpowiednich działań, zwłaszcza przez władze publiczne. Powinny się one przejawiać się przede wszystkim w wyważonej polityce pieniężnej, podporządkowanej stabilizowaniu zarówno siły nabywczej pieniądza jak i systemu finansowego, w sposób możliwie przeciwdziałający powstawaniu baniek spekulacyjnych i zagrożeń kryzysami gospodarczymi. Równocześnie wsparcia publicznego wymaga upowszechnienie i ugruntowanie w społeczeństwie wiedzy o podstawowych zjawiskach pieniężnych, zwiększającej bezpieczeństwo wszystkich uczestników transakcji finansowych.

Edukacja ekonomiczno-finansowa ma wartość samą w sobie i oczywiście problem iluzji pieniądza nie jest $w$ jej ramach ani jedynym, ani kluczowym zagadnieniem, jednakże ze względu na wyżej przedstawione uwarunkowania, przejawy i skutki jej występowania, nie należy tego problemu lekceważyć.

\section{IIITERATURA}

Akerlof G. A., Yellen J. (1985), Can Small Deviations from Rationality Make Significant Differences to Economic Equilibria?, "American Economic Review", LXXV.

Brunnermeier M. K., Julliard Ch. (2008), Money Illusion and Housing Frenzies, "The Review of Financial Studies", vol. 21, no. 1. doi: http://dx.doi.org/10.1093/rfs/hhm043.

Campbell J. Y., Shiller R. J. (1996), A scorecard for indexed government debt, National Bureau of Economic Research, "Working Paper Series", no. 5587. doi: http://dx.doi. org/10.2307/3585195.

Cohen R. B., Polk Ch., Vuolteenaho T. (2005), Money Illusion In The Stock Market: The Modigliani-Cohn Hypothesis, "National Bureau of Economic Research, Working Paper", 11018. http://dx.doi.org/10.1093/qje/120.2.639.

Cover J. P. (1992), Asymmetric Effects of Positive and Negative Money-Supply Shocks, "Quarterly Journal of Economics", November, 107 (4). doi: http://dx.doi. org/10.2307/2118388.

DeLong J. B., Summers L. H. (1988), How Does Macroeconomic Policy Affect Output?, “Brookings Papers on Economic Activity", 2. 
Fehr E., Tyran J.-R. (2001), Does Money Illusion Matter?, “The American Economic Review", vol. 91, no. 5. doi: http://dx.doi.org/10.1257/aer.91.5.1239.

Fehr E., Tyran J.-R. (2004), Money Illusion and Coordination Failure, Institute for Empirical Research in Economics, University of Zurich, "Working Paper", no. 177. doi: http://dx.doi.org/10.2139/ssrn.495402.

Fisher I. (1928), The Money Illusion, Adelphi, New York.

Garcia J. A., van Rixtel A. (2007), Inflation-Linked Bonds From a Central Bank Perspective, European Central Bank, "Occasional Paper Series”, no. 62.

Haltiwanger J., Waldman M. (1985), Rational Expectations and the Limits of Rationality: An Analysis of Heterogeneity, "American Economic Review", LXXV.

Harkness J. (1978), The Neutrality of Money in Neoclassical Growth Models, "The Canadian Journal of Economics" / "Revue canadienne d'Economique", vol. 11, no. 4. doi: http://dx.doi.org/10.2307/134374.

Howitt P. (1987), Money Illusion, [w:] The New Palgrave Dictionary of Economics, vol. 3, J. Eatwell, M. Milgate, P. Newman (eds.), New York.

Hull Z. (2011), Wprowadzenie do filozofii zrównoważonego rozwoju, [w:] Zasady kształtowania postaw sprzyjających wdrażaniu zrównoważonego rozwoju, W. Tyburski (red.), Wyd. Naukowe UMK, Toruń.

Modigliani F., Cohn R. (1979), Inflation, rational valuation, and the market, "Financial Analysts Journal”, 35 (3), 24-44. doi: http://dx.doi.org/10.2469/faj.v35.n2.24.

Noussair Ch. N., Richter G., Tyran J.-R. (2008), Money Illusion and Nominal Inertia in Experimental Asset Markets, Department of Economics University of Copenhagen, “Discussion Papers", no. 8-29. doi: http://dx.doi.org/10.2139/ssrn.1307717.

Raghubir P., Srivastava J. (2002), Effect of Face Value on Product Valuation in Foreign Currencies, "Journal of Consumer Research", vol. 29. doi: http://dx.doi.org/10.1086/344430.

Russell T., Thaler R. (1985), The Relevance of Quasi Rationality in Competitive Markets, "American Economic Review", LXXV. doi: http://dx.doi.org/10.1017/CB09780511 598951.025.

Sargent T. J. (2007), Rational Expectations, [w:] Concise Encyclopedia of Economics, D. R. Henderson (ed.), The Library of Economics and Liberty, 2nd ed., Indianapolis. Patrz też: http://www.econlib.org/library/Enc/RationalExpectations.html

Shafir E., Diamond P., Tversky A. (1997), Money Illusion, "The Quarterly Journal of Economics", vol. 112, no. 2. http://dx.doi.org/10.1162/003355397555208.

Thaler R. (1992), The Winner's Curse, The Free Press, New York. doi: http://dx.doi. org/10.1257/jep.2.1.191.

Tobin J. (1972), Inflation and Unemployment, "American Economic Review”, 62 (1). 